\title{
Copyright and digital academic library development in the UK.
}

\author{
MUIR, A.
}

2019

Copyright @ 2017 (Adrienne Muir). Reprinted by permission of SAGE Publications. 
Journal of Librarianship and

Information Science

\section{Copyright and digital academic and research library development in the UK}

\begin{tabular}{|c|c|}
\hline Journal: & Journal of Librarianship \& Information Science \\
\hline Manuscript ID & LIS-17-0064.R2 \\
\hline Manuscript Type: & Original Manuscript \\
\hline Keywords: & $\begin{array}{l}\text { Digital libraries, Digital publishing, Academic libraries, Copyright law, Open } \\
\text { access }\end{array}$ \\
\hline Abstract: & $\begin{array}{l}\text { Reviews the role of copyright in digital academic and research library } \\
\text { development in the UK over the last twenty-five years, drawing on policy } \\
\text { documents, legislative reviews and statutes, project documentation and } \\
\text { programme syntheses. Finds that copyright-related issues have presented } \\
\text { challenges for the development of digital libraries. UK copyright law has } \\
\text { been reformed as a result of consultative reviews, but the role of high-level } \\
\text { negotiations between stakeholder representatives and the development of } \\
\text { model and blanket licences have arguably been more effective in } \\
\text { supporting the development of digital libraries. Despite tensions between } \\
\text { libraries and publishers, gradual cultural change and the roles played key } \\
\text { players such funding councils and high-level representative groups has } \\
\text { facilitated progress. The increasing trend towards open licensing presents } \\
\text { new roles for libraries as well as challenges and new business opportunities } \\
\text { for publishers. Concludes it is unclear what future UK copyright and } \\
\text { research policy will be, but it is likely that improved access to academic } \\
\text { resources and research will continue, the roles of libraries and publishers } \\
\text { will continue to evolve and new sources of tension and challenges will } \\
\text { arise. }\end{array}$ \\
\hline
\end{tabular}




\title{
Copyright and digital academic library development in the UK
}

\begin{abstract}
Reviews the role of copyright in digital academic and research library development in the UK over the last twenty-five years, drawing on policy documents, legislative reviews and statutes, project documentation and programme syntheses. Finds that copyrightrelated issues have presented challenges for the development of digital libraries. UK copyright law has been reformed as a result of consultative reviews, but the role of high-level negotiations between stakeholder representatives and the development of model and blanket licences have arguably been more effective in supporting the development of digital libraries. Despite tensions between libraries and publishers, gradual cultural change and the roles played key players such funding councils and high-level representative groups has facilitated progress. The increasing trend towards open licensing presents new roles for libraries as well as challenges and new business opportunities for publishers. Concludes it is unclear what future UK copyright and research policy will be, but it is likely that
\end{abstract}


improved access to academic resources and research will continue, the roles of libraries and publishers will continue to evolve and new sources of tension and challenges will arise.

\section{Keywords}

Digital libraries, digital publishing, copyright law, academic libraries, open access

\section{Introduction}

There has been a great deal of change in how academic and research libraries provide access to resources in the last twenty five years or so. A major driver for change has been digitisation and the development of digital networks. All the major stakeholder groups in digital libraries have been involved in implementing change or have been affected by it. The rate and degree of change has been greatest in developed countries, but some developments have the potential to increase access to resources in less-developed parts of the world that 
have been disadvantaged by traditional scholarly publishing business
models.

The United Kingdom (UK) has been an active participant in exploring the potential of digitisation, digital publishing and information and communication technologies in the context of academic and research libraries and publications. The UK is an interesting case study in the development of digital libraries. A national programme of research and development was launched in the 1990s (see below), which resulted in a range of outcomes and further initiatives that paved the way for improved access to knowledge.

Copyright is a crucial issue for libraries as almost all library services involve activities that could infringe copyright. This includes digitising collections, lending and otherwise providing access to digital resources. Libraries services are provided in agreement with copyright holders, and usually require some form of financial compensation. This is done through various means, including exceptions to copyright, licence agreements and other arrangements, 
such as the UK's Public Lending Right for public libraries. Library budgets not only have to cover the cost of purchase or subscriptions for resources in their collections, but also the costs for other uses such as copying and reformatting to meet the needs of their communities.

In the context of academic and research libraries, traditional scholarly publishing models have involved the control of intellectual property by publishers. There have been tensions between intermediaries such as publishers and libraries as research and education communities have sought to harness the potential of information and communication technologies to innovate in research and the provisions of access to the outcomes of research. Progress has not always been smooth because of the uncertainties of the potential economic impact of innovations on businesses built on exploiting intellectual property rights.

The UK government has had to balance the perceived need to encourage the digital economy with a commitment to increasing 
access to the results of publicly funded research. Copyright has been perceived by some stakeholders as a barrier to increasing access to these results, but it has also been used to increase sharing of this knowledge, in a controlled way, through licence agreements. A good deal of progress has been made through the negotiation of model and blanket licences, more so than through legal reform. The cultural change towards open licensing is currently providing opportunities and challenges for libraries and publishers. A major aspect of this is an increasing commitment to open access, not just to research outputs, but also research data.

The aim of this paper is to review the role of copyright in the development of digital academic and research libraries in the UK, identifying the key issues, developments and players that have made an impact on progress. A key theme that emerges is the seeming incompatibility with the core role of libraries in facilitating access to knowledge with an economic model of intellectual property rights. This paper concentrates on the UK as a case study as it involves strong national support for research and development for digital 


\begin{abstract}
libraries and open research, coupled with government commitment to the digital economy; strong commitment on the part of publishers for licensed use on intellectual property and lobbying groups for libraries and the research and academic communities. While scope of the paper is limited to the UK, the lessons emerging from this example are potentially relevant to other countries.
\end{abstract}

\title{
Research and development in digital libraries in the UK
}

There has been research and development activity in digital libraries in many countries for many years ${ }^{\mathrm{ii}}$. An interesting aspect of activity in the UK has been the national programme funded by its higher education funding councils. The 1993 Joint Funding Councils iii Libraries Review Group (Follett) Report (HEFCE, 1993 paras 48-74) reported the results of a review carried out in response to concerns about the impact on academic library services of the expansion of the HE sector, the rising costs of scholarly publication and limited library budgets. The focus of the review was how information and communication technologies could be applied to libraries and 


\begin{abstract}
scholarly publishing to address issues of concern. This included sharing information across UK campuses and international networks, digital publishing and the digitisation of existing resources. The socalled Follett Report acknowledged copyright concerns [para. 75-76] and recommended that solutions to the copyright issues should be investigated through the funding of a small practical pilot project involving higher education institutions and publishers [para. 351]. Another recommendation was that demonstrator digitisation projects, including the development of copyright management systems, should be funded [para. 361].
\end{abstract}

The Electronic Libraries Programme

In response to the Follett recommendations, the UK funding councils' Joint Information Systems Committee ${ }^{\mathrm{iv}}$ initiated the Electronic Libraries (eLib) programme. Jisc's approach was to initially fund a large number of projects under a number of strands of activity (Rusbridge, 1998). This allowed experimentation with different approaches to the similar issues in the creation, storage and delivery of digital books, journals, images, pre-prints and on-demand 


\begin{abstract}
publishing (Whitelaw and Joy, 2000). Jisc commissioned evaluations of each phase of the eLib programme (Whitelaw and Joy 2000, 2001). These evaluations and the Tavistock Institute's synthesis of the 1997 eLib project annual reports highlighted the difficulties faced by the on demand publishing and electronic reserve projects in "overcoming the myriad difficulties connected with copyright clearance, protection and charges" (Tavistock Institute, 1999: p. 9).
\end{abstract}

Two successful eLib projects in this context were Academic COurse Readings via Networks (ACORN) and Scottish On-demand Publishing Enterprise (SCOPE). A key element of Project ACORN was the emphasis on good relations with academics and publishers (Gadd and Kingston, 1998: pp.3-4). The 1997 Tavistock made the following comment on project-publisher relations:

\author{
... the lack of an adequate mechanism or procedure to support \\ effective dialogue with publishers as stakeholders. There were \\ notable exceptions here (ACORN for example, which set up a \\ Participating Publishers Seminar) but our impression from reading
}


the annual reports is that most projects dealt with publishers on an individual, case by case basis, rather than engaging with them as part of a broad process of dialogue (Tavistock Institute, 1999: p. II, 3).

While ACORN's participating publishers did not view the provision of electronic journal articles to undergraduate students as a serious potential threat to their businesses, an important aspect of the publishers seminar was they were able to voice their concerns over issues such as access and security mechanisms (Gadd and Kingston, : p. 9) and the project team were able to provide reassurances. Another feature of Project ACORN that contributed to its success was a partnership with a trusted intermediary, Swets \& Zeitlinger BV. The ACORN project team was responsible for developing a process for negotiating and managing copyright clearances. Swets provided publisher contact details and allowed the project to include the company logo in permission request letters to publishers. Swets also directly facilitated some of the clearances and undertook scanning of journal articles for the 


\begin{abstract}
electronic reserve service as most publishers were unable to provide digital copies (Gadd and Kingston, 1998: pp. 8-10).
\end{abstract}

The SCOPE project tackled the more contentious activity of a publishing on-demand service. As with ACORN, SCOPE aimed to provide a service for undergraduate students. In SCOPE's case, this effectively involved printed and electronic course packs provided on demand from a resource bank of digitised short extracts (Pickering and McMenemy, 1999). The project was undertaken under the aegis of the Scottish Consortium of Research Libraries (SCURL) and the aim was to deliver material to students in member institutions. Unlike the ACORN project, which asked for permission to use publishers' material without payment, the SCOPE project developed a mechanism for royalty payments. Another feature of SCOPE was the development of model licences for publishers. Publishers differed in their views on appropriate models for calculating payments, including appropriate page rates and flat fees (Pickering and McMenemy, 1999: p. 215). It was up to academics and publishers to agree fees. These were sometimes successfully 


\author{
negotiated and sometimes the academics decided not to include \\ material if they thought expected fee was too high. As with ACORN, \\ publishers were wary of online delivery of their material, but were \\ also reassured by the project team on security and access \\ (Pickering and McMenemy, 1999: p. 219).
}

The first e-Lib programme evaluation included a conclusion that was true of the ACORN and SCOPE projects:

\begin{abstract}
... elib projects have helped stimulate many companies within the publishing industry into taking positions on electronic information and into addressing and clarifying their perspectives on intellectual property rights, and on charging structures. (Tavistock Institute, 1999: p. II, 7).
\end{abstract}

\begin{abstract}
A key conclusion from the initial phases of the elib programme was that a centralised copyright clearance operation would facilitate the development of digital services. The SCOPE project team was
\end{abstract}


successful in its bid for funding to run the Higher Education Resources On Demand (HERON) service. HERON's aim was to streamline rights clearance and digitisation through the development of processes and software (McRory and Curry, 2000). The eLib programme manager (Rusbridge, 2001), commented that HERON was:

... a great project battling against very difficult conditions to provide a valuable service to HEIs and to publishers. Membership is growing rapidly, as is usage amongst members. This is a genuine case where, after much hard work and many drafts of business models, a business strategy may have been identified. The important thing here is to devise sustainable ways that copyright material can be used with clear, known and reasonable costs, and at short notice.

This comment reflects Jisc's role in the development of digital academic libraries: providing funding to explore issues and develop demonstrators, then withdrawing with the expectation that a continuing service would have to find a viable business model. 
HERON was able to use of the Copyright Licensing Agency's Rapid Clearance Service (CLARCS) digitisation licence, which was introduced in 1999. The CLARCS licence was a transactional, rather than a blanket licence. However, clearing house services, such as CLARCS, could potentially ease the administrative burden of clearing rights. The nascent services did always run smoothly as Gadd (2001) found in her study of copyright clearance in UK libraries. It was clear from responses from libraries that they had received an inconsistent level of service from CLARCS (Gadd 2001 pp. 20-21) in terms of speed and helpfulness of staff. One of the qualitative responses on the HERON service was telling with regard to the costs of clearing rights. The respondent was "aware that using HERON is important to Higher Education Institutions ... it gives us a stronger negotiating position to lower fees." (p. 21).

Secker and Morrison (2016, pp. 53-55) have described the unpopularity of the transactional approach to copyright clearance in the UK HEI sector and subsequent demise of CLARCS as a service for this sector. Universities UK and GuildHE negotiated the inclusion of 
digitisation in the CLA's blanket licence. Aspects of the licence have been re-negotiated to reduce cost and reporting burdens on the sector (Copyright Licensing Agency 2016).

When its Jisc funding came to an end, HERON became a commercial service run by the publishing technology companies, Ingenta and then Publishing Technology Ltd. HERON continued as commercial service until the end of 2016 when the Copyright Licensing Agency (CLA) took over its service and then developed its Digital Content Store service for educational institutions. ${ }^{\vee}$ The cottage industry of copyright clearance for creation and use of digital library materials has moved to the mainstream and rights holders through their collecting agencies have developed solutions to meet the needs of library customers.

While progress was being made on digitisation, another issue was emerging. Jisc did not withdraw completely from supporting digital library developments, funding studies of copyright and preservation and further developing model licences to meet the needs of digital 
libraries and their users ${ }^{\mathrm{vi}}$. The CURL Exemplars in Digital Archives (CEDARS) eLib project identified copyright as a barrier to digital preservation and produced some guidance on intellectual property rights in this context ${ }^{\mathrm{vii}}$. Later studies put copyright issues on the international agenda and were part of a process towards legislative reform in the UK (Ayre and Muir, 2004; Besek et al., 2008). The problems included copyright exceptions that were no longer fit for purpose and inconsistent across jurisdictions, and contracts and technological protection measures over-riding preservation exceptions. The findings of Besek et al. (2008) were presented at the World Intellectual Property Organization (WIPO) International Workshop on Copyright and Preservation (2008) viii. WIPO's Standing Committee on Copyright and Related Rights then carried out a study of limitations and exceptions for libraries in 2008, which was most recently updated by Krews in 2015, but it is not clear whether any real changed has emerged as a result of WIPO deliberations on this.

The take-up of electronic journal subscriptions by academic and research libraries was helped along by the UK funding councils' 1995 


\begin{abstract}
Pilot Site Licence Initiative (PSLI), which later became the National Electronic Site Licence Initiative (NESLI). The NESLI licence is the basis for the current Jisc Collections model licences. ${ }^{\text {ix }}$ These licences address the various issues identified by research, development and library services, including user rights, access by off-site and walk-in users of libraries persistent access to journals included in subscriptions and archiving of content.
\end{abstract}

\title{
Reforms of UK copyright law relevant to digital libraries
}

Recent UK copyright reforms have included changes relevant to digital academic and research libraries. UK legal deposit law has also been reformed to include digital publications. The law now makes provisions for legal deposit libraries to engage in web archiving and to provide on-site access to and preserve digital legal deposit collections without infringing copyright (Legal Deposit Libraries Act 2003; The Legal Deposit Libraries (Non-Print Works) Regulations 2013). There are, however, limitations to these reforms that may not make sense to researchers. As Ballard (2013) points out, copyright material that 


\begin{abstract}
was once freely available on the internet is now only accessible from the premises of a legal deposit library
\end{abstract}

The Hargreaves review of the UK's intellectual property frameworks made recommendations on exceptions to copyright that are relevant to academic and research libraries. Most of these recommendations were implemented in 2014 and included amendments to address identified shortcomings in the scope of existing copyright exceptions (Copyright, Designs and Patents Act 1988: ss. 29 \& 42). Two of the changes are meant to intended to improve access for people with disabilities (Copyright, Designs and Patents Act 1988: ss. 31A and 31B). There were also recommendations for new exceptions, including for text and data analysis for non-commercial research (Copyright, Designs and Patents Act 1988: s. 29A), which applies whatever contractual agreements say to the contrary. This exception potentially allows researchers to lawfully carry out new forms of research based on large-scale analyses of material in digital library collections. However, responses to the UK government's consultation on the Hargreaves proposals indicated that this exception is 
unpopular with publishers who would prefer to only allow this activity under licence (HM Government, 2012: p. 17). There have been reports (Mounce, 2016) that, in practice, large-scale mining of scholarly literature has been hampered by technological protection measures to prevent copyright infringement, such as limiting the number of items that can be downloaded in one go, or slowing the speed at which such downloads occur. There is a mechanism to appeal against these measures being used to prevent lawful users exercising their freedoms under copyright exceptions (Copyright, Designs and Patents Act: s. 296ZEA). The Intellectual Property Office (2015) has reported that only nine complaints were made between 2003 and 2014. All of these were in regard to computer programmes and none were upheld. It remains to be seen whether the mechanism will be used in the context of text and data analysis in future. Another issue of concern has been how researchers can download content for analysis. A prominent example is Elsevier's policy that this activity should be licensed and researchers should register to access Elsevier's own application programming interface (Elsevier, 2017). 
While formally published material of interest to users of academic and research libraries is increasingly available in digital form, there is still potentially useful material that could be digitised to increase its accessibility. This includes orphan works. A work is an orphan if the rights holder of the work is not known or cannot be found to ask permission to use the work. Research carried out for the Strategic Content Alliance and Collections Trust (Korn, 2009) attempted to quantify the extent of orphan works in the public sector, including universities and libraries. The report comments on the volume of orphan works of academic but little commercial value that are unused because of difficulties in tracing rights owners. The Hargreaves Review favoured a licensing solution for the use of orphan works, which is now in place (Enterprise and Regulatory Reform Act 2013; Intellectual Property Office 2016). This is more suited to commercial use of copyright works than to digitisation of library collections to improve access. The UK also now has a new copyright exception through the European Union Orphan Works Directive (2012/28/EU). The exception is much narrower in scope than the licensing scheme: it allows for certain uses of orphan works by certain types of 


\begin{abstract}
organisation for non-commercial purposes. However, this would allow non-profit academic and research libraries to preserve and/or digitise orphan works to make them more accessible.
\end{abstract}

\title{
Impact of copyright reform and research and development work on the development of digital academic and research libraries
}

It is clear that early efforts to develop digital libraries raised copyright issues for academic and research libraries and concerns among publishers and other rights holders. At a practical level, UK-based digital library projects encountered difficulties in acquiring permissions from rights holders to digitise content and to provide seamless services based on this content. Digitisation of content by projects was necessitated largely because publishers were not offering digital versions of scholarly publications at the time. Publishers participating in digital library projects were interested in experimenting. There was concern that they could lose control over 


\begin{abstract}
their intellectual property and that their business models would be damaged. These difficulties were not limited to the UK; they were also experienced by projects and rights holders in other countries, including the EU's digital library programme (EBLIDA, 1999).
\end{abstract}

There were tensions between publishers and libraries in the early stages of digital development, and differences of perspective on how to move forward. As far as the eLib programme was concerned, with some exceptions, efforts to engage with rights holders were limited. However, a great deal of progress has been made at a higher level. Jisc has been an influential player, funding research and development activities and working with other stakeholder groups such as the UK's Publishers Association (PA) during the eLib programme ${ }^{i x}$.

Disputes between libraries and rights holder groups over digitisation continue to this day. ${ }^{\times}$Apart from Jisc, there are several bodies in the UK that have a role in supporting the development of digital academic and research libraries. The UUK/GuildHE Copyright Working Group 
$(\mathrm{CWG})^{\mathrm{xi}}$ has negotiated copyright licences with collective licensing organisations. The CWG also advises its members on copyright issues and responds to proposals relating to copyright. Society of College, National and University Libraries' (SCONUL) strategic vision includes a national digital library and SCONUL is a member of the CWG. SCONUL and the practitioner members of the CWG are able to communicate such issues to the senior management of HEIs through this UUK/GuildHE group.

Another body that is concerned with the identifying and communicating the impact of copyright law and the need for reform is in the UK is Libraries and Archives Copyright Alliance (LACA). LACA's mission is to advocate "a fair and balanced copyright framework which respects the rights of copyright holders whilst placing equal value on the importance of users' liberties" (Libraries and Archives Copyright Alliance, 2017). LACA has academic and research library members and is an active group, running campaigns, responding to consultations, writing to policy makers and collaborating with partner groups in Europe and beyond. Most recently, LACA has focused on 
copyright exceptions, orphan works and lending of digital publications (Libraries and Archives Copyright Alliance, 2017). It is hard to say what direct impact LACA has had on government and publisher policies, but it has certainly raised awareness of the impact of copyright issues on libraries.

\title{
Another approach to licensing: the impact of the open access movement on digital libraries
}

\begin{abstract}
A development that has the potential to really open up access to knowledge and research is the growth of the open access movement. The negotiation of model licences over time has had a great impact on the ability of libraries to provide digital content and services. The Creative Commons family of licences (Creative Commons, 2017) is widely used for publications. It is built on copyright, but has a different approach to rights. Instead of reserving rights, the licences facilitate sharing and re-use of resources with the proviso of acknowledgement of the original authors.
\end{abstract}


In the UK and elsewhere, research funders (Research Councils UK, 2017) and academic communities are embracing open access, not just to improve access to research outputs, but also to increase transparency in research and re-use of research data. This trend is being reinforced in the UK by the research funding councils grant conditions $^{\mathrm{xii}}$ and through the Research Excellence Framework ${ }^{\mathrm{xii}}$, a periodic evaluation exercise which has funding implications for education institutions. The impact on libraries includes the opportunity to take on new roles in providing access to knowledge, through managing institutional repositories, facilitating discovery of open access publications and advising researchers.

This cultural shift is a challenge to commercial publishers who have been introducing various versions of open access, introducing author pays models and/or embargo periods before publication become openly accessible. It is not yet clear what the future of academic publishing models will be, but it is likely that academic and research libraries will be able to enhance their ability to facilitate access to digital content for their communities. 


\section{Future policy on copyright and digital libraries}

The UK's future policy making has become less certain since it started the process of withdrawing from the European Union on 29 March 2017. It is not clear how copyright policy in the UK will develop and what impact this might have on academic and research libraries. The UK government plans (Department for Exiting the European Union, 2017) to convert EU law into UK domestic law through a European Union (Withdrawal) Bill. After the UK has left the EU, parts of this body of law will undoubtedly be repealed and/or changed to meet policy goals. The key question is what those policy goals will be and whether copyright and access to academic knowledge will have any place in the UK government's policy agenda.

The UK could change its copyright law post-Brexit, but there might be strong commercial and political reasons not to do so, at least in the short term. The UK intellectual property framework has recently been reformed with the aim making it fit for the digital economy. Trade with the European Union post-Brexit may limit the extent to which 


\begin{abstract}
the UK could dispense with the elements of its copyright regime that came from the EU Directives.
\end{abstract}

It may be that rights owners feel that the new economic situation will merit renewed lobbying of government to roll back recent reforms and strengthen copyright protection. However, it is not clear whether the government would be persuaded or whether it would be a priority. There is no obvious reason for funding bodies to withdraw open access mandates either, given that this is an international trend which the UK can exploit to ensure a high international profile for its academic institutions and research. As far as libraries are concerned, LACA (2016) has indicated that it will seek clarification from government officials of the impact of withdrawal from the European Union on libraries and continue to work to increase fairness in copyright.

\title{
Conclusions
}


There is no doubt that digital access to knowledge through academic and research libraries in the UK has greatly improved since the publication of the Follett Report in 1993. While there have been reforms to update the law and address issues that have arisen, it is the way that copyright law is interpreted and used by various stakeholders that is the key issue in the digital environment. The opportunities offered by digital technologies are not being fully exploited. Improvements have been largely driven by academic and research community representatives. Rights holders and their representatives have been resistant to change but have responded with digital offerings and more affordable licensing solutions when the demand has become abundantly clear.

The impetus towards open access to publications and research continues and it is not fully clear how the relative roles of intermediaries between academic knowledge and its consumers will evolve. Academic and research libraries have increased scope to provide access to and preserve academic knowledge through copyright exceptions and increasingly open content. For publishers, 
traditional approaches to economic exploitation of intellectual property in this context could become less important and provision of new services around it become more prominent. For example, Elsevier has acquired services such as Mendeley, the Social Science Research Network and Bepress. No doubt, this is a sensible business strategy, but it may result in a different form of control over the research process and research outputs.

It is probably reasonable to assume no change in government policy on copyright, at least in the short-to-medium term. Future development is more likely to be driven by the needs of research communities, the desire of libraries and other services to support these needs and negotiation and innovation between libraries and publishers. It is unlikely that the tensions between these stakeholders will lessen in future; it is more likely that it is the sources of tension will change. 


\section{Notes}

i See https://www.plr.uk.com/allAboutPIr/whatIsPIr.htm for information on Public Lending Right.

ii See Chowdhury (2003) and Andrews and Law (2005) for discussion of early activities.

iii The Higher Education Funding Council for England, Scottish Higher Education Funding Council, Higher Education Funding Council for Wales and the Department of Education for Northern Ireland.

iv The JISC became a not-for-profit company and charity in 2006 and is now known as Jisc. The latter term is used in the rest of this paper for consistency. Jisc provides digital infrastructure and services for higher and further education.

vhttps://www.cla.co.uk/digital-content-store ${ }^{v i}$ http://www.jisc-collections.ac.uk/Support/How-Model-Licences-wvi vii http://www.ukoln.ac.uk/metadata/cedars/ viiihttp://www.wipo.int/meetings/en/details.jsp?meeting_id=16162 ix See http://www.ukoln.ac.uk/services/elib/papers/pa/intro.html for reports and papers resulting from this work, including an early model licence. 
${ }^{\mathrm{x}}$ For example, Authors Guild v. HathiTrust, 755 F.3d 87 (2d Cir. 2014), United States

${ }^{x}$ http://www.universitiesuk.ac.uk/policy-andanalysis/Pages/copyright-working-group.aspx

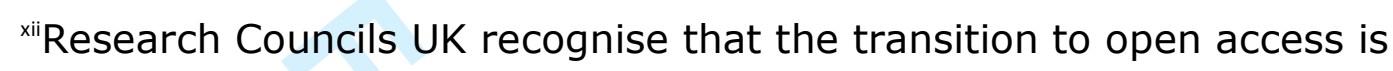
a process and for the moment the RCUK policy applies to peerreviewed articles and conference papers (Research Councils UK (2017). However, there is some discussion and movement towards open access licensing of monographs. See, for example, Jubb (2017: pp. 175-196).

xiii The most recent exercise was in 2014 http://www.ref.ac.uk/

\section{References}

Andrews J and Law DG (2005). Digital libraries: policy, planning and practice. Aldershot: Ashgate.

Ayre C and Muir A (2004). Right to preserve? Copyright and 
licensing for digital preservation project: final report. AHRB Grant number B/RG/ AN9255/APN14549. Loughborough: Loughborough University. Available from: https://dspace.Iboro.ac.uk/2134/343 (Accessed 13 February 2017).

Ballard M (2013). Copyright compromise keeps UK internet archive offline. Computer Weekly 13 Dec. Available from:

http://www.computerweekly.com/news/2240211019/Copyrightcompromise-keeps-UK-internet-archive-offline (Accessed 30 January 2013).

Besek JM et al. (2008). International study on the impact of copyright law on digital preservation: a joint report of The Library of Congress National Digital Information Infrastructure and Preservation Program, The Joint Information Systems Committee, The Open Access to Knowledge (OAK) Law Project and The SURFfoundation (2008). Available from: http://www.digitalpreservation.gov/documents/digital_preservation_fi nal report2008.pdf. (Accessed 13 February 2017). 
CEDARS (2002). CEDARS guide to intellectual property rights.

Available from:

http://web.archive.org/web/20040720105639/http://www.leeds.ac.u

k/cedars/guideto/ipr/guidetoipr.pdf (Accessed 30 January 2017).

Chowdhury, GG (2003). Introduction to digital libraries. London:

Facet.

Copyright, Designs and Patents Act 1988. c. 48.

Copyright Licensing Agency (2016). Higher education licence 2016-

2019. Available at:

https://www.cla.co.uk/sites/default/files/CLA HE Licence 2016 19-

old.pdf (Accessed 22 August 2017).

Creative Commons (2017). Share your work. Available at:

https://creativecommons.org/share-your-work/ (Accessed 13 July

2017). 
Crews, K (2015). Study on copyright limitations and exceptions for libraries and archives. SCCR/30/3. Available from:

http://www.wipo.int/edocs/mdocs/copyright/en/sccr_30/sccr_30_3.p dfhttp://www.wipo.int/edocs/mdocs/copyright/en/sccr 17/sccr 172. pdf (Accessed 1 August 2017).

Department for Exiting the European Union (2017). Legislating for the United Kingdom's withdrawal from the European Union. Cm 9446. London: HMSO.

Directive 2012/28/EU of the European Parliament and of the Council of 25 October 2012 on certain permitted uses of orphan works.

Elsevier (2017). Text and data mining. Available from: https://www.elsevier.com/about/our-business/policies/text-and-datamining (Accessed 12 July 2017).

Enterprise and Regulatory Reform Act 2013. 
GADD, E (2001). Clearing the way: copyright clearance in UK Libraries. LISU Occasional Paper No. 31. Available from:

https://dspace.lboro.ac.uk/dspace-

jspui/bitstream/2134/4338/1/Whole\%20Project\%20Report.pdf

(Accessed 22 August 2017).

Gadd E and Kingston P (1998). Project ACORN final report.

Loughborough: Loughborough University. Available from:

https://dspace.lboro.ac.uk/2134/4339 (Accessed 12 July 2017).

Hargreaves, I (2011). Digital opportunity: a review of intellectual

property and growth. Available from:

https://www.gov.uk/government/uploads/system/uploads/attachmen

t_data/file/32563/ipreview-finalreport.pdf (Accessed 25 January 2017). 
HEFCE (1993). Joint Funding Council's Libraries Review Group: report

(The Follett Report). Available from:

http://www.ukoln.ac.uk/services/papers/follett/report/ (Accessed 8 February 2017).

HM Government (2012). Consultation on copyright: summary of responses June 2012. Available from:

https://www.gov.uk/government/uploads/system/uploads/attachmen

$\underline{t}$ data/file/320223/copyright-consultation-summary-of-responses.pdf (Accessed 12 July 2017).

Intellectual Property Office (2016). Copyright: orphan works. Available from: https://www.gov.uk/guidance/copyright-orphanworks (Accessed 12 July 2017).

Intellectual Property Office (2014). Complaints to Secretary of State under s.296ZE under the Copyright, Designs and Patents Act 1988. Available from: 
https://www.gov.uk/government/uploads/system/uploads/attachmen

t data/file/440384/ipo-foi-2014-432-complaints-to-secretary-of-

state-under-s 296ze-cdpa.pdf (Accessed 12 July 2017).

Joint Information Systems Committee and Publishers Association

(1998). Guidelines for fair dealing in an electronic environment.

Bristol: Joint Information Systems Committee; London: Publishers

Association. Available: from

http://www.ukoln.ac.uk/services/elib/papers/pa/fair/intro.html, (accessed 30 January 2017).

Korn N (2009). In from the cold: an assessment of the scope of 'orphan works' and its impact on the delivery of services to the public. Available from:

https://www.webarchive.org.uk/wayback/archive/20140615221324/h ttp://www.jisc.ac.uk/media/documents/publications/infromthecoldv1. pdf (Accessed 1 August 2017).

Legal Deposit Libraries Act 2003. Eliz. II. 
The Legal Deposit Libraries (Non-Print Works) Regulations 2013. S.I. 2013/777.

Libraries and Archives Copyright Alliance (2017). Mission statement and objectives. Available from:

https://www.cilip.org.uk/research/topics/copyright/laca-librariesarchives-copyright-alliance (Accessed 13 July 2017).

Libraries and Archives Copyright Alliance (2016). LACA statement on the EU referendum result. Available from:

https://www.cilip.org.uk/research/topics/copyright/copyrightbriefings-statements (Accessed 13 July 2017).

McRory, L and Curry, S (2000). Higher Education Resources ON demand - the HERON service. Vine 30(1): 35-38.

Mounce, $\mathrm{R}$ (2016). The right to read is the right to mine: Text and data mining copyright exceptions introduced in the UK. LSE Impact 
Blog 4 June. Available from:

http://blogs. Ise.ac.uk/impactofsocialsciences/2014/06/04/the-rightto-read-is-the-right-to-mine-tdm/ (Accessed 12 July 2017).

Pickering $\mathrm{H}$ and McMenemy D (1999). Widening the SCOPE: Higher Education Resources on Demand (HERON). Program 33(3): 213-223.

Research Councils UK (2017). RCUK policy on open access and supporting guidance. Available from:

http://www.rcuk.ac.uk/documents/documents/rcukopenaccesspolicypdf/ (Accessed 13 July 2017).

Rusbridge, C (1998). Towards the hybrid library. D-lib July/August. Available from:

http://www.dlib.org/dlib/july98/rusbridge/07rusbridge.html (Accessed 12 July 2017). 
Rusbridge, C (2001). After eLib. Ariadne 26. Available from: http://www.ariadne.ac.uk/issue26/chris (Accessed 13 February 2017).

Secker, J and Morrison C (2016). Copyright and e-learning: a guide for practitioners. $2^{\text {nd }}$ ed. London: Facet.

Sieghart, W (2013). An independent review of e-lending in public libraries in England. Available from:

https://www.gov.uk/government/publications/an-independentreview-of-e-lending-in-public-libraries-in-england (Accessed 1 August 2017).

Tavistock Institute (1999). Electronic Libraries Programme: synthesis of 1997 project annual reports. Bath: UKOLN. Available from: http://www.ukoln.ac.uk/services/elib/papers/elibsynth/97synthesis.pdf (Accessed 9 February 2017).

Whitelaw, A and Joy, G (2000). Summative evaluation of phases 1 and 2 of the eLib initiative: final report. Guildford: ESYS Limited. 
Whitelaw, A and Joy, G (2001). Summative evaluation of phase 3 of the eLib initiative: final report. Guildford: ESYS Limited.

World Intellectual Property Organization (2008). International Workshop on Copyright and Preservation. Available from: http://www.wipo.int/meetings/en/2008/cr wk ge/ (Accessed 1 August 2017). 